\title{
HOW SATISFIED ARE THE INHABITANTS OF THE BALATON REGION WITH THEIR SETTLEMENT?
}

\section{Hajnalka FEKETE-BERZSENYI ${ }^{\mathrm{a}}$, Zsuzsanna BANÁSZ ${ }^{\mathrm{b}}$}

a, b University of Pannonia, Faculty of Business and Economics, Egyetem u. 10., Veszprém, Hungary, H8200

a senior lecturer, Department of Accountancy and Controlling, fekete-berzsenyi.hajnalka@gtk.unipannon.hu

b associate professor, Department of Quantitative Methods, banasz.zsuzsanna@gtk.uni-pannon.hu

Cite this article: Fekete-Berzsenyi, H., Banász, Z. (2020). How satisfied are the inhabitants of the Balaton region with their settlement? Deturope. 12(2), 18-38.

\begin{abstract}
The subject of the study is the satisfaction of the inhabitants of the Lake Balaton tourism development area (Hungary) with the settlement factors, compared to their importance. The research aims to answer the following two research questions. 1) Which settlement factors is the local population most dissatisfied with? 2) How strong is the relationship between the importance and satisfaction with the municipal factors, and the overall satisfaction of the locals with their settlement? The latter may also influence whether locals recommend their settlement or not as a place of residence or a destination for their acquaintances. The data used to answer the research questions are derived from a primary questionnaire survey collected during the years 2018-2019 (the sample element number is 1201 persons). Descriptive statistics and relationship analyses were applied as the method of research. From the differences between the importance of settlement factors and the satisfaction with these factors, decision-makers can infer the use of development resources if they wish to improve the well-being and quality of life of the local population.
\end{abstract}

Keywords: Balaton region, settlement factors, importance, satisfaction, quantitative analysis

\section{INTRODUCTION}

The subject of the research is the population living, working, studying, or having a second home or holiday home in the settlements of the Balaton priority tourism development area (GOV 2016) - hereinafter: The Balaton region - in Hungary. The study aims to determine which local (municipal) factors should be developed in the settlements of the Balaton region to increase the satisfaction of the population. The examined 27 local (municipal) factors can be classified into the following categories: municipal services, economic characteristics, factors related to leisure and tourism, demographic factors, settlement conditions.

The significance of the research is given by the fact that, to the best of our knowledge, the above research questions have not been examined for the Balaton region so far. However, the importance of individual municipal factors and satisfaction with them may guide decision- 
makers in directing regional and settlement development decisions and development resources towards improving the well-being and the quality of life of the population of the Balaton region.

The settlements provide the space for the functioning of the society (Vaszócsik \& VajdovichVisy, 2017), and there is a clear correlation between sticking to the settlement and the intention to stay in place (Tóth-Kaszás, 2018). The opinion of the population about their settlement has an impact upon the attractiveness of the settlement, immigration and emigration, tourism there, and indirectly on its competitiveness. Dissatisfaction with residential factors is in a weak, positive relationship with the willingness to migrate, that is, the intention to move (Piskóti, Nagy, Molnár, \& Marien, 2012).

The further part of the study is composed of six chapters, the first of which summarises the literature on measuring the importance of and satisfaction with municipal factors, and the second describes the data used, the research model and the research method. The following chapters present the results, the discussion, conclusions, and, finally, the findings are summarised.

\section{THEORETICAL BACKGROUND}

The examined Balaton region has special characteristics. The biggest lake of Hungary, and, at the same time, of Central-Europe, is located here, so, as a significant tourist destination, it plays an important role in the economic life of the country. This region deserves attention from an international point of view because it is the most visited region by foreign tourists after the capital (Budapest) from June to September (HCSO, 2020). The region includes 174 settlements, 42 of which are located along the shores of Lake Balaton. As the extent of the Balaton region is defined by a government decree (GOV 2016), only a few of the classical spatial organizational characteristics (unified spatial structural unit, natural characteristics, socioeconomic characteristics, cultural identity, territorial administration functions (Nemes Nagy, 1998, 2016)) prevail. The landscape and natural homogeneity of the region is rather a characteristic only of the coastal settlements, as well as the similarity of the socio-economic characteristics, mainly due to the tourism there. The Balaton region defined by the above government decree has an administrative function, and it can be considered as "a scene for the solution of common territorial development, tourism, economic development, and environmental protection problems" (Oláh, 2013).

In the next two subsections, the literature on measuring importance is summarised first, and then that of measuring satisfaction. 


\section{Measuring the importance of municipal factors}

This chapter reviews surveys in which locals were asked only about the importance of settlement factors, but did not assess how satisfied they were with them. In summarizing the relevant literature, we aimed to answer the following two questions. What settlement factors are usually listed in the research relevant to the region examined by us (Hungary)? This served as a guide for compiling our questionnaire. What were the results of this research (what is the ranking of settlement factors according to their importance)? This ensures that our results will be comparable with previous Hungarian results.

Whereas our topic deals with a region and its municipalities, we must also mention the concept of regional competitiveness, which has a wide literature, since regions compete with each other (Vaszócsik \& Vajdovich-Visy, 2017), moreover, the regional dimension of the competition has intensified (Koltai, 2017). Regional science emphasizes the spatial dimension of structures and processes in an interdisciplinary approach (Rechnitzer, 2016). The competitiveness of localities, regions, and cities is becoming increasingly important for the economy (Pike et al, 2006). Camagni (2008) found that each region has a unique territorial capital, so the return on investment also differs at different points in the space. The competitiveness of regions and towns is more than the productivity of inputs, it means economic growth that can be achieved by high employment, and improves the average standard of living (Lengyel, 2000, 2016; Begg, 1999). Porter (1990) concluded (as a result of his analysis of corporate and industry competition strategies) that competitive advantages are rooted in the regional base. Social competitiveness (e.g., effective government, education) is a fundamental dimension of territorial competitiveness (Camagni, 2002; Gardiner, Martin \& Tyler, 2004). Political considerations also play a major role in the competitiveness of regions (Chesire \& Gordon, 1996; Scott, 1998; Leitner \& Sheppard, 1998). According to Florida (2002), the key to economic success is that a region or city attracts the creative class.

It is important to know what would increase the satisfaction of the population of a region - in our case, the Balaton region - about their settlement, and thus their standard of living. It is also essential to assess how important each municipal factor is to the residents because settlements have limited resources and are often unable to meet all requirements (Marien, 2012).

Most of the models developed to measure the competitiveness of geographical areas (countries, regions, municipalities) are based on so-called "hard" indicators that can be extracted from statistical databases. These analyses, based on past statistical data, are well complemented by questionnaire surveys for the present and the future, as they can measure the 
"soft" indicators that can also examine the underlying socio-economic processes. Nevertheless, questionnaire surveys are less frequently used, during which the most engaged, locals are asked what they think about the advantages and disadvantages of their settlements (Koltai, 2005).

Koltai's research conducted in 2004-2005 (Koltai, 2005) sought to answer the question of which criteria the Hungarian population preferred when choosing the place of residence, and which settlements they considered competitive. In the course of his questionnaire survey, he formed the following variable groups: 1) services: health care, education, municipal infrastructure, urban roles, transport connections; 2) existence: employment conditions, leisure opportunities, housing stock; 3) environment: living environment, natural conditions; 4) human factors: history and traditions, demography. Koltai $(2015,2016)$ repeated the 2004-2005 research in 2012-2013, in which some new variables were also included. The category of infrastructure, assessed as the most important one in the previous study, was divided into four elements - gas supply, drainage and sewerage, Internet access and mobile networks, and road network. In this latter survey, the existence of administrative possibilities and the development of the commercial network appeared among urban roles. The ethnic composition of the population and the safety of the settlement were included as independent categories, and the previous educational conditions were supplemented by the existence of pre-school and primary education factor. In Koltai's research results, the order of importance of municipal factors (starting from the most important one) in 2004-2005 was as follows: infrastructure, transportation, employment, health care, living environment, education, urban roles, leisure time, natural conditions, housing stock, demography, history; while in the 2012-2013 research: public safety, infrastructure provision, living environment, health care, employment, primary education, transportation, administrative possibilities, ethnic composition, commercial network, natural conditions, leisure opportunities, overall educational infrastructure, characteristics of housing stock, age composition, and traditions. The division of municipal infrastructure into four parts did not result in significant differences.

The research group of the University of Miskolc also dealt with factors characterizing settlements, settlement marketing and identification with territorial identity (Marien, 2012; Piskóti, Nagy, Molnár \& Marien, 2012; Piskóti, Nagy, Dankó, Molnár, \& Marien, 2013). In the course of their research, 36 factors were examined concerning the Hungarian population, and 7 factors were defined. In order of importance of strengthening identification these are:

- essentials (6): job opportunities, public education facilities, health care and services, public security, economic development, place tidiness 
- atmosphere (3): natural characteristics, geographical location and accessibility, history and traditions

- environment (4): quality of the environment and surroundings, standard of infrastructure, demographic features of the population, real estate features

- services (9): entertainment facilities, leisure sports facilities, public transport and parking facilities, shopping facilities, restaurants and hospitality, place picture and architecture attraction, public institutions, tourist attractions, residents' friendliness

- place management (6): work of major's office, environmentally conscious place development, health-conscious place development, work of municipality, liveliness and democracy of local public life, local rules and regulations

- $\quad$ price (2): property prices, plenty of residents

- plus (6): cultural and art life, the success of competition sports, presence and standard of higher education, fairness and activity of the local media, famous people of the place, development and operation of the civil sphere.

Tab. 1 summarizes the main data and results concerning the Hungarian municipal factors of the above-described research on importance.

Table 1 Population questionnaires on the importance of municipal factors and their main results, Hungary

\begin{tabular}{|c|c|c|c|c|c|}
\hline & \multirow[t]{2}{*}{ Years } & \multirow{2}{*}{$\begin{array}{c}\text { Sample } \\
\text { size } \\
\text { (persons) }\end{array}$} & \multirow{3}{*}{\begin{tabular}{|c|} 
The \\
number of \\
variables \\
examined
\end{tabular}} & \multicolumn{2}{|c|}{ The three } \\
\hline & & & & most & least \\
\hline & \multicolumn{2}{|c|}{ of the research } & & \multicolumn{2}{|c|}{ important municipal indicators } \\
\hline $\begin{array}{l}\text { Koltai, } \\
2005\end{array}$ & $2004-5$ & 1300 & 12 & $\begin{array}{l}\text { - infrastructure } \\
\text { - transportation } \\
\text { - employment }\end{array}$ & $\begin{array}{l}\text { - housing stock } \\
\text { - demography } \\
\text { - history }\end{array}$ \\
\hline $\begin{array}{l}\text { Koltai, } \\
2015,2016\end{array}$ & $2012-3$ & 1000 & 20 & $\begin{array}{l}\text { - public safety } \\
\text { - infrastructure provision } \\
\text { - transport connection }\end{array}$ & $\begin{array}{l}\text { - history } \\
\text { - traditions } \\
\text { - age and ethnic composition } \\
\text { of the population }\end{array}$ \\
\hline $\begin{array}{l}\text { Piskóti et } \\
\text { al., 2012; }\end{array}$ & \multirow[t]{2}{*}{2011} & \multirow[t]{2}{*}{1603} & \multirow{2}{*}{$\begin{array}{l}36 \\
\text { (classified } \\
\text { into } 7 \\
\text { factors) }\end{array}$} & \multirow{2}{*}{$\begin{array}{l}\text { Within the „essentials” } \\
\text { factor: } \\
\text { - public security } \\
\text { - place tidiness } \\
\text { - job opportunities }\end{array}$} & \multirow{2}{*}{$\begin{array}{l}\text { Within the ,plus” factor: } \\
\text { - development and operation } \\
\text { of the civil sphere } \\
\text { - the success of competition } \\
\text { sports } \\
\text { - famous people of the place }\end{array}$} \\
\hline $\begin{array}{l}\text { Marien, } \\
2012 ; \\
\text { Piskóti et } \\
\text { al, 2013 }\end{array}$ & & & & & \\
\hline
\end{tabular}

Source: Authors' summary based on the mentioned literature.

After 2016, no survey was conducted in which only the importance of Hungarian settlement factors was assessed because these surveys are being replaced by those that (also) assess how satisfied people are with these. 
So far, the literature studying the importance of municipal factors has been examined, and in the next subsection, we will move on to those that measured the satisfaction with them as well as their importance.

\section{Measuring the importance and satisfaction of municipal factors}

The analysis of the difference between importance and satisfaction was widespread primarily in marketing, but it is now a methodology used in several fields of science: tourism research (Boley, McGehee, \& Hammett, 2017), destination competitiveness analysis (Dwyer, Dragićević, Armenski, Mihalič, \& Knežević Cvelbar, 2016), assessment of the services provided by tourist attractions (Pasaribu, Waryono, \& Saputra, 2016), evaluation of franchise systems in travel agencies (Ramirez-Hurtado, 2017). It has also proven to be a useful tool in other fields of science, such as in the analysis of service quality and client satisfaction in banks (Nyarku \& Oduro, 2017), or in the analysis of the quality of urban public transport (Hernandez, Monzon, \& de Oña, 2016).

Insch and Florek (2010) found that most aspects of urban life are in a positive correlation with the overall satisfaction of the residents with their settlements. Factors they examined were: work/life balance; personal and public safety; natural environment; the city's community assets (parks, gardens, historic buildings, museum, university); cultural, arts and creative scene; city's vibrancy and energy; the openness of residents; sports grounds and facilities; accessibility; efficient public transport.

The Kano model, which also appeared first in marketing science, can also be used in the analysis of satisfaction with municipal factors (Horton \& Goers, 2019; Marien, 2013). The starting point of the model is that the population does not evaluate each factor equally, they do not equally contribute to their general satisfaction. This corresponds with the usefulness, harmfulness, or neutrality of public goods known from microeconomics. The Kano model defines five quality elements:

1. One-dimension: useful goods, the more the better.

2. Attractive: also useful goods, but their absence is insignificant.

3. Must-be: also useful goods, the absence of which causes great dissatisfaction.

4. Indifferent: neutral goods, they do not have an impact on satisfaction.

5. Reverse: so-called bad goods, the less the better.

The so-called „gap” models (examining the „gap” between importance and satisfaction) based on measuring satisfaction generally focus on development priorities on areas of low consumer satisfaction. However, selecting areas for development solely on the basis of low satisfaction 
indicators is not necessarily the best method. Areas of high importance and low satisfaction should be developed the most (Chen, Yang, Lin, \& Yeh, 2007). Therefore, if the actual satisfaction is to be improved, importance and satisfaction should be conducted in parallel. At the same time, areas of less importance but high performance should be treated with caution, as there may be basic attributes whose presence does not cause satisfaction, but their disappearance can cause dissatisfaction (Boley, McGehee, \& Hammett, 2017).

Marien (2015) found that competitive settlements are those that can retain their residents and may be able to attract further residents as well. Satisfaction with the most important factors increases general satisfaction, which has a population-retaining power. In the research on the Northern Hungary region, the most critical importance-satisfaction gaps appeared in the areas of employment opportunities, health care and public safety.

Simultaneous evaluation of importance and satisfaction may tend respondents to rate the importance of variables higher than performance. For instance, in a research on Serbia, respondents rated importance higher than satisfaction for all variables (Dwyer et al., 2016).

It has already been mentioned in the introduction that the present study aims to determine which municipal factors should be developed in the settlements of the Balaton region to increase the satisfaction of the population.

The study examined the following two research questions (Q).

Q1. Which are the local (municipal) factors that residents of the Balaton region want to develop the most? This is the main research question. In the course of our research, we are seeking to answer which factors related to the Balaton region make residents consider their settlements attractive, which are the factors that are considered important for their quality of life, and how satisfied they are with the quality of these factor in their settlements. These factors can be mapped in the form of a questionnaire survey. Just as Lengyel (2003) highlighted the importance of regional specialization, we also took into account that the Balaton region although it includes not only the coastal areas - is a highly tourism-specific area, so we tried to integrate the factors serving this into our questionnaire. For people to love living in a given settlement, social factors, such as public safety, improvement of living conditions, health care, environmental protection, are considered more important than economic ones (Szirmai \& Váradi, 2009). Such factors have also been taken into account when defining our examined indicators.

Q2. Which local (municipal) factors (regarding their importance and the satisfaction with them) are in the strongest relationship with how satisfied residents of the Balaton region are with their settlement as a whole, and whether they would recommend it to their acquaintances as a place of residence or travel destination? This research question is motivated by the idea mentioned in 
the introduction that satisfaction with local factors has an impact on the attractiveness of the settlement.

\section{DATA AND METHODS}

The research is based on primary data collection which was carried out in two years (2018 and 2019) so far. There was no significant change in the circumstances affecting the Lake Balaton region during the 1 year between the two surveys. With the survey, individuals were asked who study or work in the Balaton region defined in 2016 (GOV, 2016), or own a second home there. Thus the sample was not homogeneous, considering e.g. respondents 'attachment to the region, but increasing the satisfaction of all of them is in the interest of the leaders of the settlements. Therefore, the present study aims to provide a comprehensive picture of the opinions of people associated with the region. The 844 evaluable questionnaires collected in 2018 were expanded by an additional 357 in 2019, so the size of the total evaluable sample (n) means the opinion of 1201 people. Previous studies have already reported the results of the 2018 survey (Lörincz, Lang \& Banász, 2019; Banász \& Biermann, 2019; Fekete-Berzsenyi, 2019). The present research examines the issues that were included in the survey of both years. Although this sample cannot be considered representative, it typically covers the social stratum whose views may be most relevant to municipal decision-makers in defining long-term development strategies. They are those young people who possessed a higher education or secondary level education qualification. With regard to qualifications at least $86 \%$ of the sample completed at least the secondary school (12\% did not want to declare their education and $2 \%$ finished primary school). In terms of age, almost $90 \%$ of the sample reported it and half of the respondents were under 37.

The research model of Table 2 lists the survey questions which we take into account in the study as response variables (A) and the potential explanatory variables (B). We would like to explain (A) the satisfaction of the residents of Balaton with their settlement (A1), and thus whether they would recommend their settlement to their acquaintances, either as a place of residence (A2) or as a holiday destination (A3). These (A) questions could be answered on a scale of 1 to 10 , with 1 representing the worst answer and 10 the best. The importance (B1-27) and the satisfaction with (B28-54) 27 local (municipal) factors are used as potential explanatory variables. These (B) questions could be answered on a scale of 1 to 5, where 1 means the worst answer and 5 the best. 
Table 2 Research model, 2018-9 ( $\mathrm{n}=1201)$.

\begin{tabular}{|c|c|c|c|c|}
\hline \multicolumn{4}{|c|}{ Survey questions } & Response options \\
\hline A) & \multicolumn{3}{|l|}{ Response variables } & $1-10$ \\
\hline A1 & \multicolumn{3}{|c|}{ How satisfied are you with the settlement altogether? } & $\begin{array}{l}\text { 1: completely dissatisfied } \\
\text { 10: completely satisfied }\end{array}$ \\
\hline $\mathrm{A} 2$ & \multirow{2}{*}{\multicolumn{2}{|c|}{$\begin{array}{l}\text { Would you recommend the settlement } \\
\text { to your friends and relatives as }\end{array}$}} & place of residence? & \multirow{2}{*}{$\begin{array}{l}\text { 1: I wouldn't recommend it at all } \\
\text { 10: I would fully recommend it }\end{array}$} \\
\hline A3 & & & holiday destination? & \\
\hline B) & \multicolumn{3}{|c|}{ Potential explanatory variables } & $1-5$ \\
\hline $\begin{array}{l}\mathrm{B} 1- \\
\mathrm{B} 27\end{array}$ & How important for you & \multirow{2}{*}{\multicolumn{2}{|c|}{$\begin{array}{l}\text { the listed } 27 \text { local (municipal) } \\
\text { factors? }\end{array}$}} & $\begin{array}{l}\text { 1: not important at all } \\
\text { 5: very important }\end{array}$ \\
\hline $\begin{array}{l}\text { B28- } \\
\text { B54 }\end{array}$ & How satisfied are you with & & & $\begin{array}{l}\text { 1: I am not satisfied at all } \\
\text { 5: I am completely satisfied }\end{array}$ \\
\hline
\end{tabular}

Source: Own research.

The quantitative research is based on the descriptive statistics and relationship analyses. Since each indicator can be measured on an ordinal (Likert) scale, rank correlation relationships can be interpreted. There are several indicators to measure the strength and direction of these types of relationships. Due to the high number of ties, Kendall's Tau-b coefficient is applied (hereinafter $\tau$ ). This $\tau$ varies from -1 to 1 . The sign of the number indicates the positive or negative nature of the relationship. Negative (positive) $\tau$ means that as the rank of one variable increases, the rank of another variable tends to decrease (also increase). The absolute value of $\tau$ shows the strength of the rank correlation (Hinton, McMurray \& Brownlow, 2014). We use the following classification within the interval 0-1 to determine the strength of the rank correlation (Sajtos \& Mitev, 2007):

- 0 : there is no rank correlation,

- $] 0,0.2[$ : weak,

- $\quad[0.2,0.7[$ : moderate,

- $[0.7,1[$ : strong,

- 1: deterministic relationship.

The results are interpreted at a significance level of $5 \%$.

\section{RESULTS}

\section{Descriptive statistics}

As a first step, we sum up the demographic characteristics of the sample to receive the social features of the respondents. Almost half of the respondents (49\%) are locals, who live in the Balaton region and/or works/studies here. $22 \%$ of the respondents live elsewhere but have a secondary home/holiday home in the Balaton region. $16 \%$ was the rate of locals who live in the Balaton region but works or studies elsewhere. The remaining 13\% were those who live elsewhere but works or study in the Balaton region. 
There were $31 \%$ male and $57 \%$ female respondents in the sample. The remaining $12 \%$ did not indicate their gender. According to their highest education level, most of the respondents possessed a higher education (diploma) (44\%) or secondary level education (42\%) qualification. Based on their occupation $27 \%$ were intellectual employees, followed by the students (22\%). Considering age, the mean was 38 years, the mode was 22 years and the median was 37 years. Latter two mean, that in most cases, the questionnaire was completed by 22 -yearolds, and half of the respondents were younger than 37 years old. It can be assumed that the average of opinions can also vary greatly by age group. For this reason, we examined the differences between the average opinions of younger and older people. The boundary between the two age groups was drawn at the median age (37 years). The averages of the opinions of young people and the elderly (on the importance of the 27 settlement factors and the satisfaction with them) do not differ significantly (they differed by -0.002 on average). The average of the opinions measured on a scale of 1-5 differed the most in the following two cases: the average young people rated the importance of the history of the settlement by 0.58 less and the entertainment opportunities by 0.55 more than the older ones.

In the following, we turn to the answers related to the questions presented in Table 2.

\section{A) Descriptive statistics of the response variables}

Responses included both extreme responses $(1,10)$, so the range of responses for each question was 10 units. Table 3 contains some descriptive statistics for the three variables to be explained.

Table 3 Descriptive statistics of the response variables (A1-3), 2018-9 (n=1201).

$\mathrm{V}$ : relative standard deviation

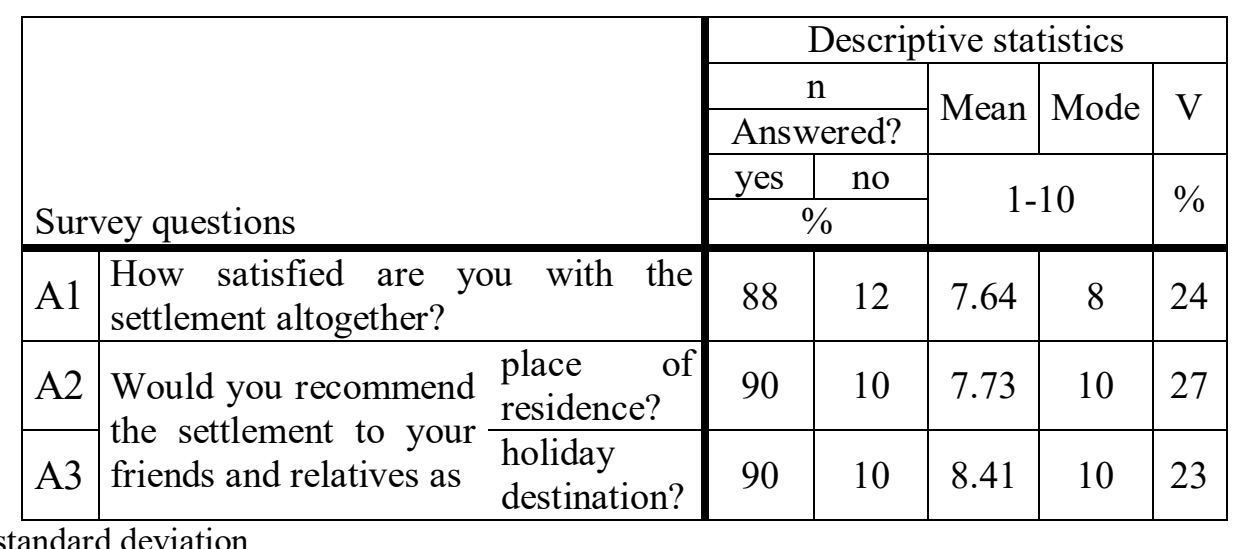

Source: Own research.

All three questions were answered by approximately $90 \%$ of the sample. On the scale of 1 to 10 , most gave the maximum score (10) to the question of whether they would recommend their settlements to their friends or acquaintances, either as a place to live or as a destination $($ Mode $=10)$. However, in terms of their overall satisfaction with the settlement, the most 
common response was slightly less, namely 8 . Regarding the means and the relative standard deviations of the responses, the following statements can be made:

- the recommendation of the settlement as a destination came in the first place, as the respondents gave the highest average score (8.41) on this question, and the opinions of individual people deviated the least from this average ( $\mathrm{V}=23 \%)$

- the settlement would be less recommended as a place to live (7.73) and even less satisfied with their settlement (7.64). The answers were more similar in terms of satisfaction with the settlement $(\mathrm{V}=24 \%)$, while in the case of recommending the settlement as a place of residence, the opinions of individual people differed the most from the average (7.73), namely by $27 \%(\mathrm{~V})$.

Overall, the residents of the Balaton region rated the response variables relatively well with a relatively high occupancy rate (about 90\%). The results also show that the settlements of the Balaton region are recommended as a destination rather than a place of residence by the locals. This may be due to the degree of overall satisfaction with the settlement. It is therefore important to know which factors should be developed to higher population well-being, quality of life.

\section{B) Descriptive statistics of potential explanatory variables}

In the following, we turn to how important and satisfied people are with the 27 settlement factors listed. Responses range from 1 to 5 . The response rate was $87-93 \%$ for the importance of settlement's factors and $77-92 \%$ for satisfaction. Table 4 contains descriptive statistics.

Table 4 Descriptive statistics of the importance and satisfaction with local (municipal) factors, 2018-9 $(\mathrm{n}=1201)$.

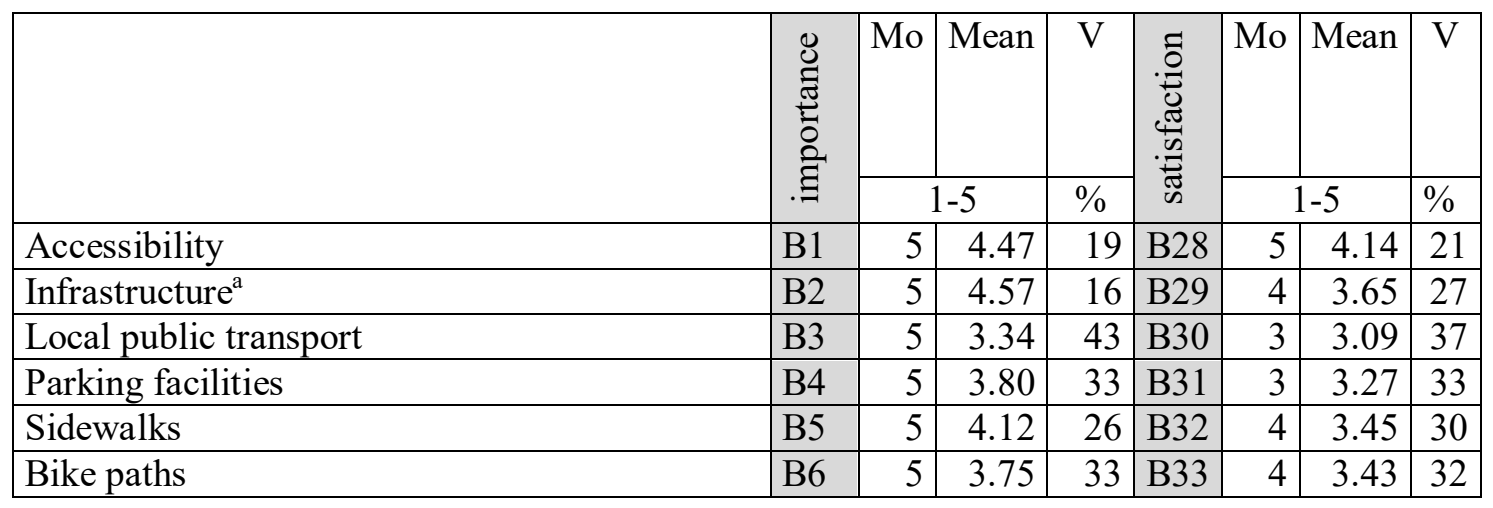


Table 4 (continued)

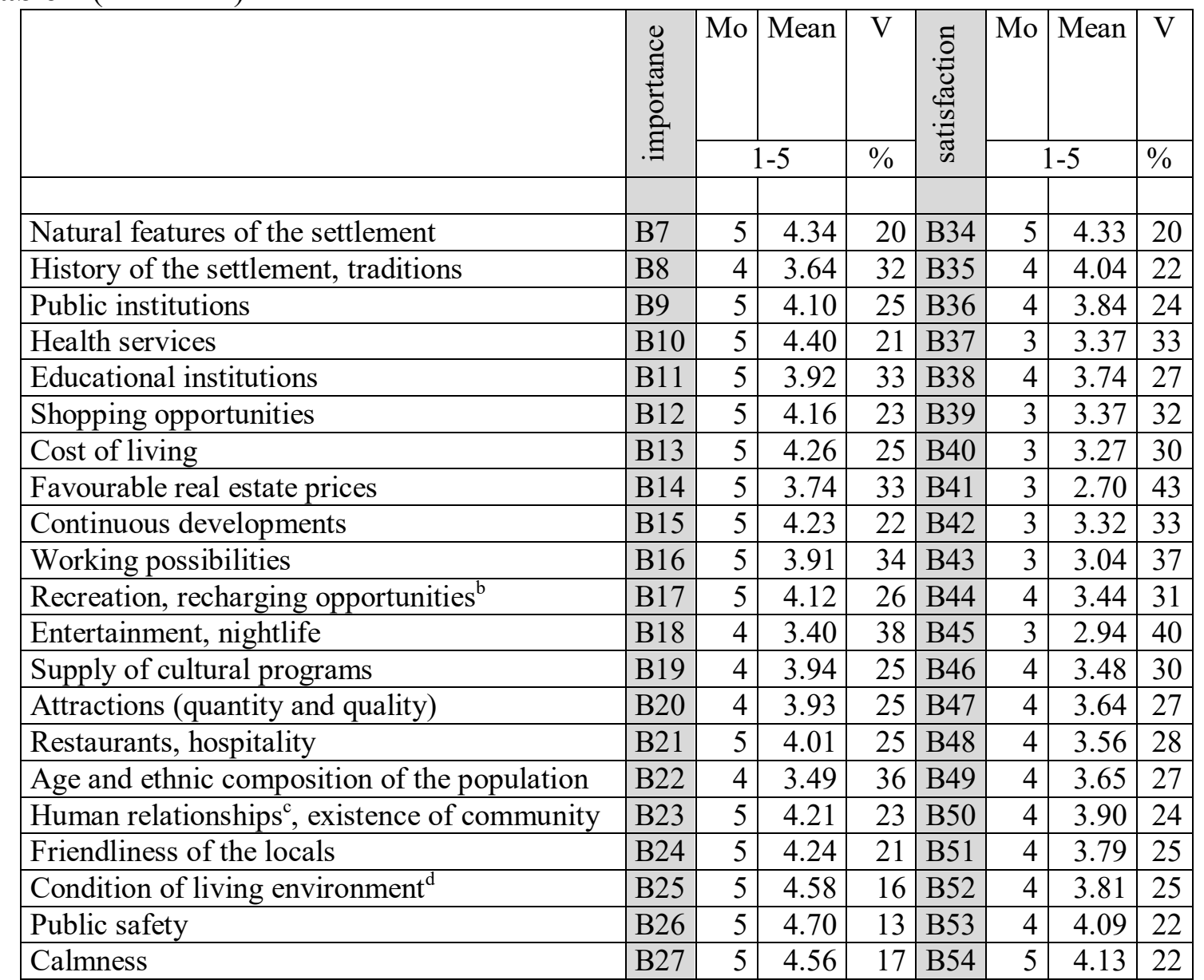

Mo: mode, $\mathrm{V}$ : relative standard deviation

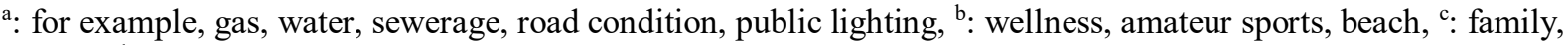
friends, ${ }^{\mathrm{d}}$ : green areas, cleanliness, orderliness

Source: Own research.

Focusing on the modes in Table 4, the following interesting observations can be made. The majority considers the importance of all settlement factors to be maximum (5), except for the following five, which are considered one degree less important (4): the history of the settlement, traditions (B8), entertainment, nightlife (B18), the supply of cultural programs (B19), the quantity and quality of attractions (B20), age and ethnic composition of the population (B22). Satisfaction shows a more varied picture. There were only 3 factors with which the majority were maximally (5) satisfied, namely: accessibility (B28), natural features of the settlement (B34) and calmness (B54). Of the remaining 24 factors, the majority are the most dissatisfied with (mode=3) the following 9: local public transport (B30), parking facilities (B31), health services (B37), shopping opportunities (B39), cost of living (B40), favourable real estate prices (B41), continuous developments (B42), working possibilities (B43), entertainment, nightlife (B45). 
The means and relative standard deviation values of Table 4 belong together. The low (high) value of the relative standard deviations shows that individual opinions differed less (more) from the mean. Figure 1 illustrates the means of Table 4.

Figure 1.a. ranks the 27 municipal factors by the average importance (from the most important to the least important), while Figure 1.b. ranks them by average satisfaction (from the factor they are most satisfied with). On average, public safety is considered the most important, while local public transport is the least important. The average resident of the Balaton region is the most satisfied with the natural endowments of the settlement and the most dissatisfied with the real estate prices.

The mean of the importance and satisfaction was almost the same for the natural endowments.

Only two factors make the average resident more satisfied than they consider important:

- history of the settlement, traditions,

- age and ethnic composition of the population.

Figure 1 Means of importance and satisfaction with local factors, 2018-9 $(n=1201)$.

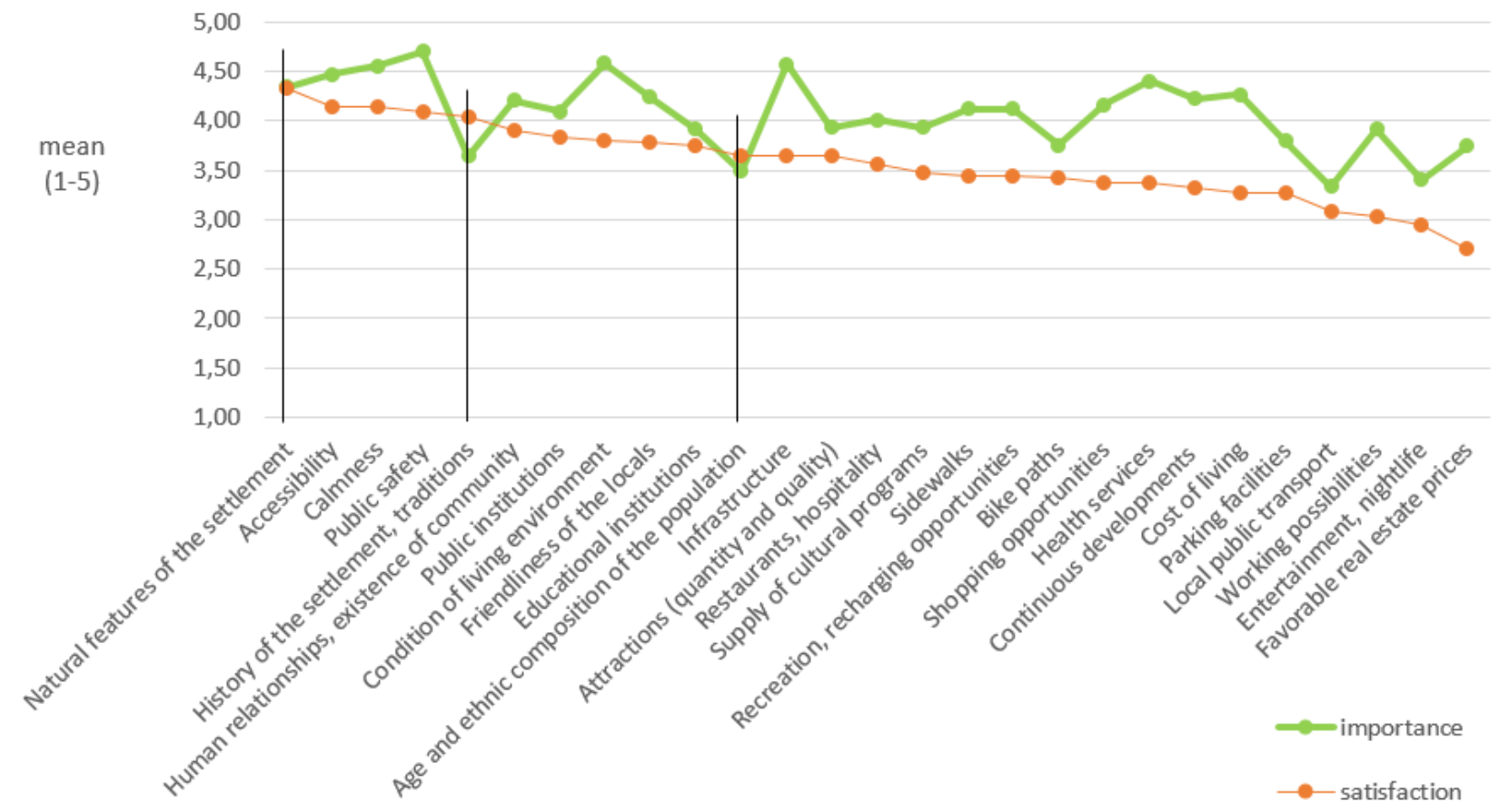

Source: Own research.

Figure 2 ranks the results by the difference between average importance and satisfaction (average importance-average satisfaction), which are quantified in Table 4. It is important because the literature suggests designating areas for improvement based on this difference. 
Figure 2 The difference between average importance and satisfaction, 2018-9 $(n=1201)$.

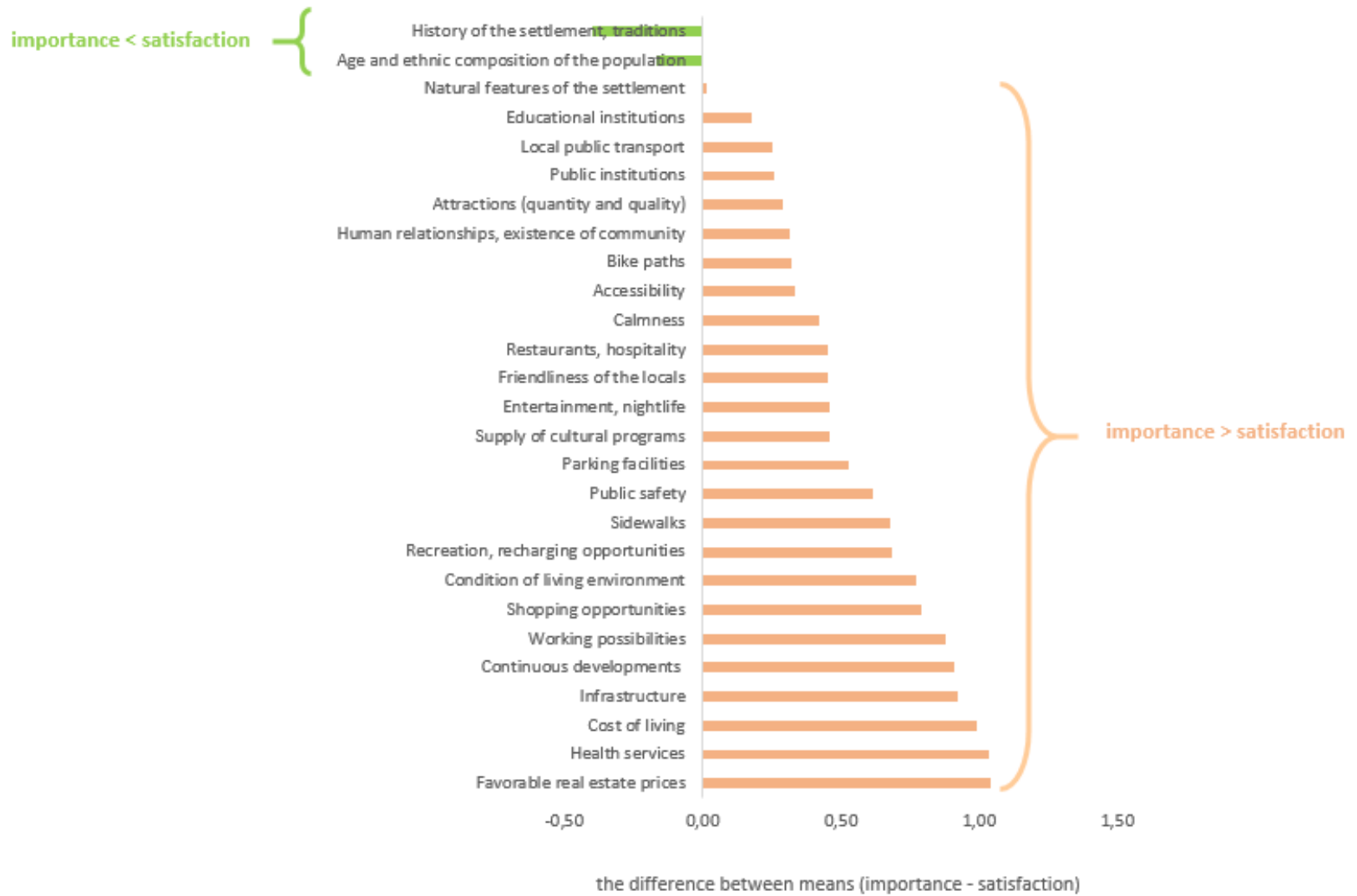

Source: Own research.

Based on the results, the top 10 settlement factors with the largest importance-satisfaction gaps are the following in Balaton region: favourable real estate prices, health services, cost of living, infrastructure, continuous developments, working possibilities, shopping opportunities, the condition of the living environment, recreation and recharging opportunities, sidewalks. Almost all of these can be influenced by local and regional decision-makers through the allocation of development resources. Unfortunately, decision-makers have the least influence on the factor with which locals are most dissatisfied, relative to its importance, that is, they have the least impact on the reduction of real estate prices. If the gap is large beside low importance, we would not recommend spending money on improving this factor. However, no such case has occurred, because the importance of all factors was rated at least moderate.

\section{Relationship analysis}

Table 5 contains the significant results of relationship analyses, i.e. $\tau$ rank correlation coefficients $(\tau)$ between response (A) and explanatory (B) variables. It shows that most of the answers to the questions are significantly related, but only weak. The green background colour 
indicates stronger relationships, which represent moderate strong relations. All significant result means positive $\tau$ values, which mean the higher the importance or satisfaction with a local factor $(B)$ is, the higher the overall satisfaction with the settlement (A).

Table 5 Results ( $\tau$ coefficients) of relationship analyses.

\begin{tabular}{|c|c|c|c|c|c|c|c|c|}
\hline & $I^{*}$ & $\mathrm{~A} 1$ & A2 & A3 & $\mathrm{S}^{* *}$ & $\mathrm{~A} 1$ & $\mathrm{~A} 2$ & $\mathrm{~A} 3$ \\
\hline Accessibility & B1 & 0.068 & 0.072 & n.s. & B28 & 0.146 & 0.164 & 0.071 \\
\hline Infrastructure & B2 & n.s. & 0.076 & n.s. & B29 & 0.237 & 0.155 & 0.145 \\
\hline Local public transport & B3 & n.s. & 0.085 & n.s. & B30 & 0.177 & 0.128 & 0.111 \\
\hline Parking facilities & B4 & n.s. & 0.062 & 0.086 & B31 & 0.154 & 0.114 & n.s. \\
\hline Sidewalks & B5 & n.s. & 0.060 & n.s. & B32 & 0.206 & 0.158 & 0.139 \\
\hline Bike paths & B6 & n.s. & 0.070 & n.s. & B33 & 0.178 & 0.174 & 0.076 \\
\hline Natural features of the settlement & B7 & 0.054 & 0.085 & 0.141 & B34 & 0.139 & 0.162 & 0.201 \\
\hline History of the settlement, traditions & B8 & 0.128 & 0.144 & 0.199 & B35 & 0.190 & 0.166 & 0.205 \\
\hline Public institutions & B9 & 0.052 & 0.164 & 0.111 & B36 & 0.186 & 0.226 & 0.163 \\
\hline Health services & $\mathrm{B} 10$ & n.s. & 0.082 & 0.083 & B37 & 0.209 & 0.152 & 0.136 \\
\hline Educational institutions & $\mathrm{B} 11$ & n.s. & 0.134 & n.s. & B38 & 0.210 & 0.246 & 0.143 \\
\hline Shopping opportunities & B12 & n.s. & 0.051 & 0.064 & B39 & 0.172 & 0.146 & 0.171 \\
\hline Cost of living & B13 & n.s. & 0.077 & n.s. & B40 & 0.214 & 0.139 & 0.065 \\
\hline Favourable real estate prices & $\mathrm{B} 14$ & n.s. & 0.085 & 0.084 & B41 & 0.137 & 0.079 & n.s. \\
\hline Continuous developments & $\mathrm{B} 15$ & n.s. & 0.102 & 0.054 & B42 & 0.329 & 0.233 & 0.187 \\
\hline Working possibilities & $\mathrm{B} 16$ & n.s. & 0.087 & n.s. & B43 & 0.239 & 0.228 & 0.167 \\
\hline Recreation, recharging & $\mathrm{B} 17$ & n.s. & n.s. & 0.071 & B44 & 0.209 & 0.118 & 0.240 \\
\hline Entertainment, nightlife & $\mathrm{B} 18$ & n.s. & n.s. & n.s. & B45 & 0.202 & 0.138 & 0.241 \\
\hline Supply of cultural programs & B19 & 0.088 & 0.121 & 0.150 & B46 & 0.276 & 0.219 & 0.272 \\
\hline Attractions (quantity and quality) & B20 & n.s. & 0.100 & 0.145 & B47 & 0.249 & 0.207 & 0.325 \\
\hline Restaurants, hospitality & B21 & n.s. & 0.050 & 0.058 & B48 & 0.160 & 0.082 & 0.166 \\
\hline Age and ethnic composition of the population & $\mathrm{B} 22$ & n.s. & 0.103 & n.s. & B49 & 0.280 & 0.238 & 0.167 \\
\hline Human relationships, existence of community & B23 & 0.060 & 0.154 & 0.074 & B50 & 0.264 & 0.232 & 0.180 \\
\hline Friendliness of the locals & $\mathrm{B} 24$ & 0.102 & 0.162 & 0.097 & B51 & 0.311 & 0.241 & 0.197 \\
\hline Condition of living environment & $\mathrm{B} 25$ & 0.053 & 0.090 & 0.067 & B52 & 0.346 & 0.214 & 0.163 \\
\hline Public safety & $\mathrm{B} 26$ & n.s. & 0.112 & 0.089 & B53 & 0.228 & 0.185 & 0.129 \\
\hline Calmness & $\mathrm{B} 27$ & 0.084 & 0.127 & 0.093 & B54 & 0.233 & 0.155 & 0.112 \\
\hline
\end{tabular}

$\mathrm{I}^{*}$ : importance, $\mathrm{S}^{* *}$ : satisfaction, n.s.: not significant result at the level at 5\%.

Colour key by the strength of the significant results: weak (] $0,0.2[)$, moderate $([0.2,0.7[)$

Source: Own research.

Overall satisfaction with the settlement and the recommendation (A1-3) are more related to satisfaction with the local factors rather than its importance. In the following, we will discuss the strongest relationships for each response variable. Overall satisfaction with the settlement (A1) is most related to the satisfaction with the following local factors:

- B42. continuous developments $(\tau=0.329)$

- B51. friendliness of the locals $(\tau=0.311)$

- B52. condition of living environment (e.g. green areas, cleanliness, orderliness) $(\tau=$ $0.346)$

The recommendation of the settlement to friends and relatives as a 
- holiday destination (A3) is the strongest relationship $(\tau=0.325)$ with the satisfaction with the quantity and quality of attractions (B47).

- place of residence (A2) is the strongest relationship $(\tau=0.246)$ with satisfaction with educational institutions (B38).

\section{DISCUSSION}

Since we would like to make suggestions for the improvement of the actual satisfaction of residents of the Balaton region with their settlements, we followed the suggestion by Chen, et al. (2007), namely, we asked the importance of municipal factors and the satisfaction with them at the same time. Our survey of 2018-2019 in the Balaton region yielded similar results to those in Koltai's (2005) study on Hungary in terms of which factors were at the beginning of the order of importance (public safety) and close to the end of the list (history of the settlement, traditions). In our research, the two factors following public safety were the condition of the living environment and infrastructure (e.g. gas, water, sewerage, road condition, public lighting). These two factors are listed in reverse order in Koltai's (2015) research. It is interesting to note that, in our research, the last two factors in the order of importance in the largest tourist region of the country are entertainment opportunities, nightlife and local public transport. It should be noted that these two factors had the largest relative standard deviation in rating importance ( $43 \%$ for local public transport and $38 \%$ for entertainment). That is, these two factors differed the most from the average. This is presumably due to the fact that only 42 of the 174 settlements are located on the shores of Lake Balaton, and many of them are small settlements, where local public transport is not even required.

Our results are in line with the findings of Insch and Florek (2010), namely, that not only the majority but all the 27 municipal factors examined in our survey are in positive correlation with the overall satisfaction of residents with their settlements.

In practical use of our results (which is shown in Figure 2), it is recommended for local and regional decision-makers to obtain development resources for the factors with which locals are most dissatisfied related to their importance (in which cases the importance-satisfaction gap is relatively large).

\section{CONCLUSION}

The three variables to be explained were rated relatively good on a scale of 1-10 by the residents of the Balaton region. Although they would recommend their settlements to their 
friends and acquaintances as a place of residence, they would rather recommend them as a travel destination.

Based on our analyses, we make the following findings for the two research questions (Q) mentioned in the Introduction.

Q1. Which are the local (municipal) factors that residents of the Balaton region want to develop the most?

Figure 2 showed the municipal factors that residents are most satisfied or dissatisfied with in terms of their importance. In our opinion, on the one hand, settlement leaders must maintain the standard of the factors with which they are relatively satisfied, ad which can be influenced by the municipality: the history of the settlement, traditions, (for example, events describing them), natural features of the settlement (for example, preventing the increase of environmental pollution). On the other hand, agreeing with the suggestion of Chen et al. (2007), it is worth focussing on the development of the factors (for example, to look for sources of tenders announced for the Balaton priority tourism development area or those available by individual settlements), with which residents of the Balaton region are the least satisfied at present, compared to how important they are.

These are the favourable real estate prices, health services, cost of living, infrastructure, continuous developments, working possibilities.

Q2. Which local (municipal) factors (their importance and satisfaction with them) are in the strongest relationship with how satisfied residents of the Balaton region are with their settlement as a whole and whether they would recommend it to their acquaintances as a place of residence or travel destination?

Satisfaction with the settlement or recommendation of it (A1-3) is more related to how satisfied individuals are with each municipal factor than to how important they considered them to be. All of the significant relationships are positive. Among them, the strongest statements are about the residents who stick to the Balaton region:

Who are more satisfied with the condition of living environment (e.g. green areas, cleanliness, orderliness), the continuous developments or the friendliness of the locals, they are also more satisfied with the settlement as a whole.

The recommendation of the settlement to friends and acquaintances as a

- holiday destination is mostly influenced by whether they are satisfied with the quantity and quality of attractions. (The more satisfied with the quantity and quality of their settlement's attractions, the more they would recommend the settlement of their friends and acquaintances as a holiday destination.) 
- place of residence is mostly influenced by whether they are satisfied with educational institutions. (The more satisfied they are with the educational institutions of their settlement, the more they would recommend their settlement to their friends and acquaintances as a place to live.)

Among these, the municipality can have the least effect on the friendliness of the population. In case the leaders of the local government in the Balaton region would like the people sticking to their settlements to be more satisfied with their settlements as a whole and also recommend them to their friends and acquaintances, this can be achieved by taking measures that will improve the conditions of their living environment, make continuous developments, increase the quality and quantity of sights and attractions, and improve educational institutions.

\section{SUMMARY}

The subject of the study was the Balaton region defined in 2016 which unites 174 settlements, including 42 settlements on the shores of Lake Balaton The research examined the satisfaction of the inhabitants of this region with the settlement factors, compared to their importance. The research aims to answer the following two research questions. 1) Which settlement factors are most dissatisfied with the local population? 2) How strong is the relationship between the importance and satisfaction with the municipal factors, and the overall satisfaction of the locals with their settlement? The latter may also influence whether locals recommend their settlement or not as a place of residence or a destination for their acquaintances. The research is based on primary data collection which was carried out in 2018 and 2019. The size of the total evaluable sample (n) was 1201. Descriptive statistics and relationship analysis were applied as the method of research.

From the differences between the importance of settlement factors and the satisfaction with these factors, decision-makers can infer the use of development resources if they wish to improve the well-being and quality of life of the local population. Our research has contributed to the exploration of the key factors that the population of the Balaton region considers important, and, from their point of view, they can be the basic pillars of long-term economic, social and environmental development. We believe that the elaboration and implementation of development strategies can be successful in terms of social perception, which are based on the needs and internal conditions of the region. Our research endeavoured to provide information for founding such development decisions. The research results can contribute to the elaboration of local developments that meet the actual needs and requirements of the population, taking into consideration that decision-makers do not necessarily influence on all the factors included in this study, and needs and requirements may largely differ in various settlements of the region. At the same time, we believe that a complex vision that takes residential needs into account is essential for making decisions that aim to improve the well-being and the quality of life of the population.

The comparison of the importance of municipal factors and the satisfaction with them helped to reveal current deficiencies that could induce future development efforts. Based on our research, the development of the following 10 municipal factors is most recommended in the settlements of the Balaton region: favourable real estate prices, health services, cost of living, infrastructure, continuous developments, working possibilities, shopping opportunities, condition of the living environment, recreation, recharging opportunities, sidewalks.

\section{Acknowledgement}

This publication/research has been supported by the European Union and Hungary and co-financed by the European Social Fund through the project EFOP-3.6.2-16-2017-00017, titled "Sustainable, intelligent and inclusive regional and city models".

\section{REFERENCES}

Banász, Z., \& Biermann, M. (2019). A Balaton térsége mint élettér I.: demográfia és munkaerőpiac. [In Hungarian, The Lake Balaton area as a living space I.: demography and labour 
market.] In J.Sulyok, Z.Banász, B.Fehérvölgyi, K.Hiezl, R.Szabó (Eds.), „Mi, balatoniak..." [in Hungarian,,,We, the people of Balaton...”]. Studies of the Balaton Tourism Research Institute (pp. 70-76). Veszprém: Pannon Egyetemi Kiadó. Retrieved from https://www.gtk.uni-pannon.hu/wp-content/uploads/2019/11/ batuki_tanulmanykotet_2018_nyomda-v3.pdf

Begg, I. (1999). Cities and competitiveness. Urban studies, 36(5-6), 795-809.

Boley, B. B., McGehee, N. G., \& Hammett, A. T. (2017). Importance-performance analysis (IPA) of sustainable tourism initiatives: The resident perspective. Tourism Management, $58,66-77$.

Camagni, R. (2008). Regional Competitiveness: Towards a Concept of Territorial Capital. In R.Capello, R.Camagni, B.Chizzolini, U.Fratesi, (Eds.), Modelling Regional Scenarios for the Enlarged Europe. European Competitiveness and Global Strategies (33-46). BerlinHeidelberg: Springer.

Camagni, R. (2002). On the concept of territorial competitiveness: sound or misleading? Urban Studies 39(13), 2395-2411.

Chen, S. H., Yang, C. C., Lin, W. T., \& Yeh, T. M. (2007). Service quality attributes determine improvement priority, The TQM Magazine, 19(2), 162-175.

Cheshire, P. C., \& Gordon, R. I. (1996). Territorial competition and the predictability of collective (in)action. International Journal of Urban and Regional Research, 20(3), 383399.

Dwyer, L., Dragićević, V., Armenski, T., Mihalič, T., \& Knežević Cvelbar, L. (2016). Achieving Destination Competitiveness: an Importance -Performance Analysis of Serbia, Current Issues in Tourism, 19(13), 1309-1336.

Fekete-Berzsenyi, H. (2019). A Balaton térsége mint élettér III.: Települési tényezők fontosság vs. elégedettség. [In Hungarian, The Lake Balaton area as a living space III.: Settlement factors - importance vs. satisfaction]. In J.Sulyok, Z.Banász, B.Fehérvölgyi, K.Hiezl, R.Szabó (Eds.), „Mi, balatoniak...” [In Hungarian, „,We, the people of Balaton...”]. Studies of the Balaton Tourism Research Institute (pp. 77-82). Veszprém: Pannon Egyetemi Kiadó. Retrieved from https://www.gtk.uni-pannon.hu/wpcontent/uploads/2019/11/batuki_tanulmanykotet_2018_nyomda-v3.pdf

Florida, R. (2002). The Rise of the Creative Class. New York: Basic Books.

Gardiner, B., Martin, R., \& Tyler, P. (2004). Competitiveness, productivity, and economic growth across the European regions. Regional Studies, 38(9), 1045-1067.

GOV (2016). 429/2016 (XII. 15.) Korm. rendelet a turisztikai térségek és a kiemelt turisztikai fejlesztési térségek meghatározásáról. [In Hungarian], Government Decree on the definition of tourist areas and priority tourism development areas]. Retrieved from https://net.jogtar.hu/jogszabaly?docid=A1600429.KOR\&txtreferer $=00000001 . T X T$

HCSO (2020). Guest nights spent in commercial accommodation by tourist region (2016-). Hungarian Central Statistical Office. Retrieved from https://www.ksh.hu/docs/hun/xstadat/xstadat_evkozi/e_oga006a.html

Hernandez, S., Monzon, A., \& de Oña, R. (2016). Urban transport interchanges: A methodology for evaluating perceived quality. Transportation Research Part A: Policy and Practice, 84, 31-43. Retrieved from https://doi.org/10.1016/j.tra.201

Hinton, P. R., McMurray, I., \& Brownlow, C. (2014). SPSS Explained. Second edition. London and New York: Routledge Taylor Francis Group.

Horton, G., \& Goers, J. (2019). A Revised Kano Model and its Application in Product Feature Discovery. Retrieved from https://www.researchgate.net/publication/332304132 A_Revised_Kano_Model_and_its_Application_in_Product_Feature_Discovery 
Insch, A., \& Florek, M. (2010). Place satisfaction of city residents: Findings and implications for city branding. In G.Ashworth, M.Kavaratzis (Eds.), Towards effective place brand management: Branding European cities and regions (pp. 191-204). Cheltenham: Edward Elgar.

Koltai, Z. (2005). A magyarországi városok versenyképességének lakossági megítélése [In Hungarian, Public perception of the competitiveness of Hungarian cities], Tér és Társadalom 19(3-4), 23-41.

Koltai, Z. (2015). Településtípusok lakóhelyi vonzerőinek értékelése [In Hungarian, Evaluation of residential attractions of settlement types]. Földrajzi Közlemények, 139(3), 213-225.

Koltai, Z. (2016). Városok vonzereje országos és regionális léptékben [In Hungarian, Attractiveness of cities on a national and regional scale], In I.Lengyel \& B.Nagy (Eds.), Térségek versenyképessége, intelligens szakosodása és újraiparosodása [In Hungarian, Regional competitiveness, smart specialization and re-industrialization] (pp. 272-289). Szeged: JATEPress.

Koltai, Z. (2017). Assessment of the attractions of the residential place in Hungary. KözépEurópai Közlemények, 10(3), 91-106.

Leitner, H., \& Sheppard, E. (1998). Economic uncertainty, inter-urban competition and the efficiency of entrepreneurialism. In T.Hal, P. Hubbard (Eds.), The Entrepreneurial City (285-308). Chichester: John Wiley.

Lengyel, I. (2000). A regionális versenyképességröl [In Hungarian, On regional competitiveness], Közgazdasági Szemle, 47, 962-987.

Lengyel, I. (2003). Verseny és területi fejlödés: térségek versenyképessége Magyarországon, [In Hungarian, Competition and territorial development: the competitiveness of regions in Hungary], Szeged: JATEPress

Lengyel, I. (2016). A megyék versenyképességének néhány összefüggése a megújult piramismodell alapján [In Hungarian, Some connections of county competitiveness based on the renewed pyramid model], In Lengyel I. - Nagy B. (Eds.), Térségek versenyképessége, intelligens szakosodása és újraiparosodása [In Hungarian, Regional competitiveness, smart specialization and re-industrialization] (pp. 143-161). Szeged: JATEPress.

Lőrincz, K., Lang, L. A., \& Banász, Z. (2019). A Balaton régió imázsa és a helyi identitás vizsgálata [In Hungarian,The image of the Balaton region and the examination of the local identity]. In J.Sulyok, Z.Banász, B.Fehérvölgyi, K.Hiezl, R.Szabó (Eds.), , Mi, balatoniak...” [In Hungarian, „, We, the people of Balaton...” ].Studies of the Balaton Tourism Research Institute (pp. 61-70). Veszprém: Pannon Egyetemi Kiadó. Retrieved from https://www.gtk.uni-pannon.hu/wp-content/uploads/2019/11/batuki tanulmanykotet_2018_nyomda-v3.pdf.

Marien, A. (2012). A sikeres településmarketing kulcsa az elégedett lakosság [In Hungarian, The key to successful settlement marketing is a satisfied population]. In I.Piskóti (Ed.), Marketingkaleidoszkóp [In Hungarian, Marketingkaleidoscope] (pp. 91-96). Miskolc: Miskolci Egyetem Marketing Intézet. Retrieved from http://www.marketingturizmus.hu/otka/n33.pdf

Marien, A. (2013). A lakossági elégedettség és a helyben maradást magyarázó tényezők összefüggései (In Hungarian, Relationships between population satisfaction and factors explaining staying in place], Marketing \& Management, 47(1), 3-10.

Marien, A. (2015). A területi identitás magatartási megnyilvánulásai, különös tekintettel a költözési szándékra [In Hungarian, Behavioral manifestations of territorial identity, in particular the intention to move]. Észak-magyarországi Stratégiai Füzetek, 12(1), 4-16. 
Nemes Nagy, J. (1998). A tér a társadalomkutatásban. Ember-település-régió sorozat [In Hungarian, Space in social research. People-settlement-region series]. Budapest: Hilscher Rezső Szociálpolitikai Egyesület.

Nemes Nagy, J. (2016). Mezoterek a társadalomban és a gazdaságban [In Hungarian, Mezospaces in society and the economy], In I.Lengyel \& B.Nagy (Eds..), Térségek versenyképessége, intelligens szakosodása és újraiparosodása [In Hungarian, Regional competitiveness, smart specialization and re-industrialization] (pp. 105-124). Szeged: JATEPress.

Nyarku K. M., \& Oduro, S. (2017). Importance-Performance Matrix Analysis (IPMA) of Service Quality and Customer Satisfaction in the Ghanaian Banking Industry. International Journal of Academic Research in Business and Social Sciences, 7(7), 532550. Retrieved from http://dx.doi.org/10.6007/IJARBSS/v7-i7/3120

Oláh, M. (Ed.) (2013). Balaton Kiemelt Térség Fejlesztési Programja Helyzetértékelés I. Balaton Fejlesztési Tanács [In Hungarian, Balaton Priority Area Development Program Situation Assessment I. Balaton Development Council], Retrieved from https://docplayer.hu/1251182-Balaton-kiemelt-terseg-fejlesztesi-programja.html

Pike, A. J., Champion, A. G., Coombes, M. G., Humphrey, L., \& Tomaney, J. (2006). The economic viability and self-containment of geographical economies: a framework for analysis. London: Office of the Deputy Prime Minister.

Piskóti, I., Nagy, S., Molnár, L., \& Marien, A. (2012). Identification between individuals and places of residence. In Conference Proceedings of Retracing the Silkroad: MAG Scholar Global Business Marketing and Tourism Conference (pp. 1-10). Retrieved from https://papers.ssrn.com/soL3/papers.cfm?abstract_id=2929245

Piskóti, I., Nagy, S., Dankó, L., Molnár, L., \& Marien, A. (2013). Paradigm of the social marketing-theoretical-methodological research. OTKA Research Reports.

Ramirez-Hurtado, J. M. (2017). The use of importance-performance analysis to measure the satisfaction of travel agency franchisees. Revista de Administração de Empresas, 57(1), 51-64. Retrieved from http://dx.doi.org/10.1590/S0034-759020170105

Pasaribu, P., Waryono, W., \& Saputra, R. (2016). Measurement of Visitor's Satisfaction through Importance Performance Analysis (IPA) Method About Servicescape. Advances in Economics, Business and Management Research, 28, 242-244. 1st International Conference on Tourism, Gastronomy, and Tourist Destination (ICTGTD 2016). Atlantis Press.

Porter, M. E. (1990). The Competitive Advantage of Nations. Harvard Business Review, 68(2), 73-93.

Rechnitzer, J. (2016). A jövő terei, a tér jövője [In Hungarian, Space of the future, the future of space]. Magyar Tudomány, 177(8), 922-936.

Sajtos, L. \& Mitev, A. (2007). SPSS kutatási és adatelemzési kézikönyv [In Hungarian, SPSS Research and Data Analysis Manual]. Budapest: Alinea.

Scott, A. J. (1998). Regions and the World Economy. London: Oxford University Press.

Szirmai, V. \& Váradi, Z. (2009). A várostérségi társadalmak versenyképesség-felfogása. [In Hungarian, Perceptions of the competitiveness of urban societies]. In V.Szirmai (Ed.), $A$ várostérségi versenyképesség társadalmi tényezöi [In Hungarian, Social factors of urban competitiveness] (pp. 185-190). Budapest-Pécs: Dialóg Campus.

Tóth-Kaszás, N. (2018). Settlement attachment and Generation Z - an example of a central city in Hungary. Deturope, 10(2), 54-74.

Vaszócsik, V., \& Vajdovich-Visy, E. (2017). Integrated land-use models for spatial planning support: country-specific solutions. Deturope, 9(3), 12-28. 